\title{
Childhood Ovarian Mixed Germ Cell Tumor
}

National Cancer Institute

\section{Source}

National Cancer Institute. Childhood Ovarian Mixed Germ Cell Tumor. NCI Thesaurus.

Code C123849.

A mixed germ cell tumor that arises from the ovary and occurs in children. 